\title{
Xenophobic societal attitudes in a "new" South Africanism: Governance of public perceptions, national identities and citizenship
}

\author{
J TSHEOLA' ${ }^{1}$ T RAMOROKA AND L MUZONDI ${ }^{3}$
}

\begin{abstract}
This article argues that xenophobia is not a natural state of being for any society; instead, it is a product of socialisation which becomes excessive with violent abuses of the outgroup immigrants where such conduct is institutionalised through state apparatus. In this context, post-apartheid South Africanisms cannot be generalised as intrinsically xenophobic because the dreadful societal attitudes and violent abuses are evidently products of institutionalized governance for socialization of public perceptions of hostilities and animosities through the politics and struggles of politico-socio-economic resources. The coinage and officialdom of rainbowism was admission that construction of a new national identity around culture was a virtual impossibility; and, the result was usurpation of exclusionary citizenship that came to define insiders away from outsiders. This notion of citizenship promised access to state and pubic resources, which did not materialise, leading to frustration against government and targeting of out-group African immigrants. Hence, the apparent "felt" collective threat among in-group communities against out-group immigrants over the untenable alibi of job and women stealing as well as acceptance of below minimum wages are inherently functions of irrational jealousy. This article frames this argument through a rigorous examination of the theorisation of xenophobia as "new racism", models of governance of xenophobic societal attitudes for public hostilities, animosities and violent abuse. Furthermore, it examines constructions of new South Africanism, African Renaissance, exclusionary citizenship, exceptionalism, differentness and the society's frustration with politico-socio-economic resources exclusionism amidst constitutional inclusivity, tolerance, cultural pluralism, inviolate human rights and the political elitism's hyperbolic public stunts of a better life for all.
\end{abstract}

Keywords: xenophobia, governance, public perceptions, societal attitudes, exclusionary citizenship, collective threat, exceptionalism; South Africanism

\section{Introduction}

In their article on racialization of the African immigrants in post-apartheid South Africa, Adjai \& Lazaridis (2013) frame xenophobia as the "New Racism". Their contention is that the modeling of racism along colour divides "as a single overarching factor shaping racial and ethnic relations" is inadequate and that it has to be conceptualised through "the interplay of

1. Faculty of Management \& Law, University of Limpopo, P.O. Box 313, Fauna Park, 0787, South Africa, johannes.tsheola@ul.ac.za

2. Department of Development Planning \& Management, University of Limpopo, P.O. Box 313, Fauna Park, 0787, South Africa, millicent.ramoroka@ul.ac.za

3. Department of Development Planning \& Management, University of Limpopo, Private Bag X1106, Sovenga, 0727, South Africa, loretta.muzondi@ul.ac.za

Td The Journal for Transdisciplinary Research in Southern Africa, 11(4), December 2015, Special edition, 
difference, diversity and cultural pluralism" which are precipitated by the politics and struggle for politico-socio-economic resources (Adjai \& Lazaridis, 2013: 192). This article questions whether South Africanism is a xenophobic expression against African out-group immigrants, given years of apartheid racism? Indeed, African immigrants have exclusively experienced discrimination, social exclusion and, importantly, violent abuse in a democratic South Africa, notwithstanding the Constitution that decrees cultural inclusivity and pluralism, tolerance and inviolate human rights (Balbo \& Marconi, 2006; Vincent, 2008; Gade, 2011; Adjai \& Lazaridis, 2013; Chinomona \& Maziriri, 2015). The article finds the locus of xenophobic societal attitudes in a democratic South Africa in the institutionalisation of exclusionary citizenship, domestically and internationally. Exclusionary citizenship implied the onset of governance of public perceptions for hostilities, animosities and violence against African outgroup immigrants through the politics and struggles over access of politico-socio-economic resources.

Xenophobia is not only emotive, just as land ownership and reform, it is also an intensely complex and multifaceted subject; and, "the relationship between the presence of immigrant population and xenophobic sentiments" (Jolly \& DiGiusto, 2014: 464) remains unresolved. To this extent, it would be a shoddy and sloppy cognitive simplicity to conclude that postapartheid South Africanism is intrinsically xenophobic, notwithstanding the evidence that most of the violent abuse witnessed is perpetrated largely by youthful people who may be younger than the democratic miracle itself. Questions of the governance of the perpetrators' institutionalised socialisation into xenophobia cannot exclude the state apparatus that deflect attention from the incapacity to deliver the promise of a better future for all. Unsurprisingly, the untenable alibi of the unjustifiable exclusive violent abuse of African immigrants around issues of job and women stealing and acceptance of below minimum wages, have been demystified as a function of irrationality and sheer jealousy (Burns \& Gimpel, 2000; Balbo \& Marconi, 2006; Jennings, 2009; Hainmueller \& Hiscox, 2010; Adjai \& Lazaridis, 2013; De Sante, 2013; Chinomona \& Maziriri, 2015).

This article draws from the longstanding literature in social psychology wherein xenophobic societal attitudes are theorised through, among other things, the extremes of contact, prejudice, power, cultural-symbolism, phenomenology, threat and economic theories as well as the egocentric pocket-book and regional economics sociotropic ideological principles. There exist a plethora of theoretical and philosophical engagements that have sought to determine the causes of xenophobic societal and public attitudes. Whereas contact and threat theories are diametrically on opposite sides of the argument about the causes of societal attitudes and public perceptions that drive animosities, hostilities, antagonism and violence against the immigrant out-groups, a meticulous scan and analysis of contextual variables will suggest that they both have variable applicability depended on the geographic scale and dominant factors precipitating xenophobia (Hainmueller \& Hiscox, 2007, 2010; Hopkins, 2010, 2011; De Sante, 2013; Jolly \& DiGiusto, 2014). Further, it is tenable to assert that in a democratic South Africa violent abuses of the African out-group immigrants in 2008 and 2015 cannot be leisurely dissociated from the argument that xenophobic expressions have intricately become unintended strategy for national citizenship self-reassurance which occurred "after intensive phases of modernization" that failed to keep up with the promises of social welfare state and a better life for all (Hjerm, 2009; Ha, 2010; Hopkins, 2011; Adjai \& Lazaridis, 2013; De Sante, 2013; Chinomona \& Maziriri, 2015). 
In this context, given the enduring legacies of apartheid racial discrimination, is South African xenophobic attitudes and evident institutionalised governance of public perceptions for socialisation into hostilities, animosities and violent abuses against the African immigrant out-groups, "new racism?" Theorisation of this question must of necessity always be a complex and sophisticated undertaking because it simultaneously draws into questioning the institutionalisation and governance of the exercise of citizenship, which is inherently exclusionary. Hence, amidst the "rainbowism nation" metaphor, the aphorism of "Ubuntu" and constitutional inclusivity and inviolate human rights, new South Africanism's search for national identity continues to be built on exclusionary citizenship that perpetrates xenophobic societal attitudes and public perceptions (Ngunjiri, 2010; Gade, 2011; Khomba, Vermaak \& Gouws, 2011; Mabovula, 2011; Adjai \& Lazaridis, 2013; Chinomona \& Maziriri, 2015). Perhaps, the question to be framed is whether or not the societal tendencies of xenophobia against the African immigrant out-groups are indicators of the post-apartheid South Africanism becoming fascist (Chinomona \& Maziriri, 2015; Mafukata, 2015). The institutionalisation and governance of public perceptions for societal hostilities, animosities and violent abuses are evidently constructed through state apparatus that drove African Renaissance and new South Africanism. Questions linking African Renaissance, South Africanism and xenophobia against the African out-group immigrants should not find expression in simplistic straightforward answers.

\section{Theorisation of xenophobia as "new racism"}

At its core, xenophobia involves dislike and fear of the out-group immigrants (Adjai \& Lazaridis, 2013; Chinomona \& Maziriri, 2015). Adjai \& Lazaridis (2013: 192) cites the World Conference Against Racism, Racial Discrimination, Xenophobia and Related Intolerance's (2001) definition of xenophobia as "attitudes, prejudices and behavior that reject, exclude and often vilify persons, based on the perception that they are outsiders or foreigners to the community, society or national identity." Chinomona \& Maziriri (2015: 20) regard xenophobia as "a buzz word" that relates to "any hostility or negative attitude or behavior" against the out-group. The deep "distrust and suspicion" against the out-group, which is potentially fatalistic, manifests along "ethno-linguistic and cultural identities," allowing for discriminatory treatment on the bases of "national origin or ethnicity" (Adjai \& Lazaridis, 2013: 192). This description explains the apparent paradoxes, ironies and contradictions in South Africa's mix of constitutional inclusivity, reconstruction of citizenship that is discriminatory, rainbowism, Ubuntu and a better life for all. The question that begs asking is: does new South Africanism expresses "new racism" and xenophobia against the African out-group immigrants? The concept of "new racism" is founded on the expressions and emphasis of differentness in terms of culture, ethnicity and nationality; and, a democratic South Africa has since 1994 usurped concepts of exceptionalism and differentness in its endeavor to champion and to take leadership of African issues ranging from security, economy to development. Under former President Mbeki, South Africa became a virtual selfselected ambassador for the rest of Africa, which was at times very unwelcome. If this conduct of international relations influenced the society's constructions of citizenship of exclusionism and discrimination against the out-group African immigrants as a threat, then there is reason to explore the resultant xenophobic attitudes, from the "new racism" perspective.

Generally, social psychology literature suggests that fear of the other plays a significant role in the manifestation of animosity, hostilities, antagonism and violence against the immigrant 
out-groups. Where societal and public animosities, hostilities, antagonism and violence are driven through perceptions that differentiate the out-group through its racial and ethnic Africanness, such attitudes would be extending xenophobia into afrophobia. However, it should suffice to state that racism, as apartheid South Africa has known, was a structural ideology governed for reproduction by "rules, laws, regulations and institutions" (Adjai \& Lazaridis, 2013: 193). Whereas this paper argues that the original seed of societal attitudes of xenophobia against out-group African immigrants was planted through official state conduct of international relations and reconstruction of citizenship, largely on behalf of the majority of the previously disenfranchised, there was no deliberate structural ideology and conscious governance for its reproduction through "rules, laws, regulations and institutions". Some scholars do trace the current xenophobic attitudes back to apartheid South Africa (see for example, Akokpari, 2002; Bernstein, 2005; Zuberi \& Sibanda, 2005; Ngoiyaza \& Rondganger, 2008; Vincent, 2008; Gade, 2011; Adjai \& Lazaridis, 2013; Chinomona \& Maziriri, 2015). This paper, though, argues that it was the present democratic regimes' attempts to break loose from the shackles of apartheid through a strongly asserted citizenship, domestically and internationally, that backfired as a matter of cumulative impact. First, it should be important to explore the theoretical formulations on the making of xenophobic societal attitudes.

\section{Contact of in-group with immigrant out-group or phenomenology}

Theoretically, "contact alone does not determine intergroup attitudes"; however, its effects are mediated through "the state of the economy or sociotropic concerns" (Jolly \& DiGiusto, 2014: 466) as well as interactions among groups. But increased contact and interactions with the out-group immigrants has been assumed to have the effect of undermining xenophobic societal attitudes and public perceptions (Brown \& Lopez, 2001; Vincent, 2008; Hopkins, 2010). The argument assumes that in the processes of interactions of the in-group and the out-group who are in pursuit of common goals, the cultural, ethnic and xenophobic stereotypes would be undermined whilst fostering "understanding, integration, and peaceable relations", notwithstanding the disparate nature of such groups (Jolly \& DiGiusto, 2014: 465). Contact theory emphasizes the common humanity and similarities of the in-group and the out-group, rather than disparities as well as "relative status and goals" which drive anxiety, suspicion, skepticism, "distorted images" and "negative stereotypes" that precipitate xenophobic conflict and violence (Brown \& Lopez, 2001; Jennings, 2009; Ha, 2010; Hopkins, 2010; Jolly \& DiGiusto, 2014). However, self-interest theory relates to individuals' personal socio-economic circumstances, which may be superseded by collective threat perceptions. Whereas interactions alter the intra-group dynamics, "the threat theory relies more clearly on simple concentration levels, as opposed to contact" (Jolly \& DeGiusto, 2014: 468).

There are several important moderating variables that need consideration, including the demographics, especially the size of the out-group, geographic scale, political rhetoric and so on (Golder, 2003; Gabel \& Scheve, 2007; Hjerm, 2009; Hopkins, 2011). The effect of contact on societal attitudes and public perceptions as well as racially-/ethnically-motivated tensions is a function of a variety of contextual variables (Brown \& Lopez, 2001; Brinegar \& Jolly, 2005; Jolly \& DeGiusto, 2014). That is, the content and magnitude of the effect of contact with the immigrant out-group on the in-group xenophobic societal attitudes and public perceptions should be examined within the contextual variable of demography, geography, politics, culture and so on. Equally, contact between in-group and out-group can 
equally "undermine" xenophobic tendencies and "exacerbate" tensions (Jolly \& DiGiusto, 2014: 471). Interactions, especially where both groups are driven by the pursuit of common goals, could potentially undermine negative stereotypes, distorted images and foster understanding, integration and peaceable relations between out-group and in-group (Hainmueller \& Hiscox, 2007; Vincent, 2008; Jennings, 2009; Ha, 2010; Hopkins, 2010; Jolly \& DiGiusto, 2014). Paradoxically, contact can trigger threat perceptions, which may as well be objectively absent, and subjective perception of vulnerability, with the resultant prejudicial attitudes, animosities and violent abuses of the out-group immigrants. In the final analysis, it can be conclusively argued that contact by itself does not precipitate xenophobic attitudes, in the absence of strong collective threat public perceptions.

\section{Societal perceptions of collective threat}

The threat theory offers a direct converse of the contact thesis; and, it is linked to economic theory on xenophobia (Burns \& Gimpel, 2000; Brown \& Lopez, 2001; Jennings, 2009; Chinomona \& Maziriri, 2015). A rudimentary tenet of the threat theory states that intergroup tensions and conflicts intensify with contact that exposes in-groups and out-groups to competition for scarce resources (Hjerm, 2009; Kopstein \& Wittenberg, 2009; Rink, Phalet \& Swyngedouw, 2009; Jolly \& DiGiusto, 2014). Generally, societal attitudes and prejudice against the out-group are driven primarily through collective threat perceptions rather than egocentric individual contact or sociotropic "objective personal economic circumstances" (Burns \& Gimpel, 2000; Hopkins, 2010; Jolly \& DiGiusto, 2014). But the defining lines between threat, economic and power theory are not necessarily vivid. Collectively, these theories attribute xenophobia to factors such as poverty, unemployment, deprivation, inequality and so on (Burns \& Gimpel, 2000; Brown \& Lopez, 2001; Zuberi \& Sibanda, 2005; Soyombo, 2008; Chinomona \& Maziriri, 2015). The contention is that it is the disgruntled, poor and unemployed citizenry, especially youth, who engage in xenophobic tendencies. According to Quillian (1995 cited in Jolly \& DiGiusto, 2014: 466), though, the "size of the out-group" and the "economic circumstances" are the two key factors that determine collective threat public perceptions.

Contact theorists themselves concede that “... higher levels of immigration at the state level especially if citizens live in homogeneous areas themselves - may actually exacerbate relations by increasing threat perceptions" (Jolly \& DiGiusto, 2014: 471). Public perception of collective threat does not necessarily have to be a direct result of the reality of competition in the job market (Burns \& Gimpel, 2000; Chinomona \& Maziriri, 2015). Strong perception of collective threat can on its own precipitate resentment, animosities, antagonism and abusive violence. From the threat theory's perspective, the size of the out-group can easily precipitate intensive collective threat in the in-group with the attendant prejudices and antagonism against immigrants (Jennings, 2009; Rink et al., 2009; Ha, 2010; Hopkins, 2010, 2011; Jolly \& DiGiusto, 2014). As Hjerm (2009) put it, antipathy against the out-group intensifies with the increase in the size of the immigrant population, which is directly correlated with the ingroup perceived collective threat. Generally, social psychology literature tacitly insinuates that "perceptions of collective threat", rather than contact between the in-group and the outgroup or "their objective personal economic circumstances" drive societal and public attitudes of animosity, hostility, antagonism and violence (Jolly \& DiGiusto, 2014: 466). That is, egocentric and sociotropic considerations do not necessarily determine societal xenophobia outside the effects of the size of the out-group, on collective threat public perceptions. 


\section{Egocentric and sociotropic theses}

Notwithstanding the association of threat theory with economic theory on xenophobia, competition for economic resources should not necessarily be fundamental to the causes of animosities, antagonism and abusive violence against the out-groups. Instead, "culturalsymbolic theory" points to in-groups' sense of exceptionalism and differentness (Hainmueller \& Hiscox, 2007, 2010; Vincent, 2008; Ha, 2010; Chinomona \& Maziriri, 2015; Mafukata, 2015), which is consistent with the ongoing theorisation of xenophobia as "new racism." According to Jolly \& DiGiusto (2014: 465), "Identifying how contact with immigrant populations and political economic conditions shape public opinion, especially racist or xenophobic attitudes, is essential to understanding public attitudes to racial minorities and immigrants ..." Basically, the egocentric and sociotropic theses are established on the bases of political value judgments of differentness and exceptionalism (Kessler \& Freeman, 2005; Hjerm, 2009; Jennings, 2009; Hopkins, 2011; Mafukata, 2015), wherein societal perceptions are exceptionally exposed to state governance that creates, wittingly or unwittingly, xenophobic attitudes. This observation is perfectly applicable to the South African xenophobic situation because it was never contact by itself that drove societal attitudes and public perceptions of animosities, hostilities, antagonism and violence against African immigrant out-groups. Instead, certain hidden variables altered the public moot and agitated it against the African out-groups that lived in the communities for years prior to the social upheavals. The businesses that were looted and the African immigrants who were violently displaced and/or killed lived in the localities as neighbors. The xenophobic attacks started exclusively in the informal settlements and/or townships, diffusing to city centres, where poverty and basic services access is severely constrained. In this context, governance becomes a critical variable in drawing insight into the necessary and sufficient causes of xenophobic public attitudes and perceptions. Hence, evidence shows that out-group African immigrants are generally entrepreneurial and that they create jobs (Akokpari, 2002; CDE, 2006; Chinomona \& Maziriri, 2015; Mafukata, 2015). Governance is crucial to shaping societal attitudes and public perceptions because mere contact with the out-groups does not by itself precipitate conflict and violence. Evidence suggest that some of the African out-group immigrants who were attacked in South Africa in 2008 and 2015 owned a variety of small businesses. Apparently, the mediating effects of the constructions of South Africanism through African renaissance and exclusionary citizenship precipitated societal sense of exceptionalism and differentness associated with egocentric and sociotropic propensities. The role of the state and the political elite in driving African Renaissance and exclusionary citizenship cannot be discounted.

\section{Governance and political elitism}

In contrast to modified contact theory, Jolly \& DiGiusto (2014: 465) find that “... political economic conditions matter ... while the presence of large immigrant populations is associated with diminished local xenophobia”. Indeed, political party rhetoric and elite manipulation are also critical in the creation of collective threat perceptions as well as hostilities (Gabel \& Scheve, 2007; Jennings, 2009; Hopkins, 2010, 2011; De Sante, 2013). As a result, "animosity toward multiculturalism at the elite level will correlate with xenophobia at the individual level" (Jolly \& DiGiusto, 2014: 468). In this way, Jolly \& DiGiusto (2014) are contend that scientific analyses of xenophobia should incorporate political party rhetoric, politicisation of national-scale interactions, perceptions of threat and political elite manipulation as well as rational economic factors, beyond mere personal 
ideologies, individual self-interests and egocentrism at localities. Necessarily, interpretations of societal attitudes and public perceptions of xenophobic animosities, hostilities, antagonism and violence against the immigrant out-groups should be cognitively sophisticated (Jennings, 2009; Hopkins, 2010, 2011; Jolly \& DiGiusto, 2014). For this reason, scientific examination of xenophobia should necessarily entail meticulous care in order to eschew the entrapment of the inherent paradoxes and ironies of the caliber of those perpetrated through polities. In the latter, it is the norm to have public stunts that assume rejection of xenophobia when in practice politicisation of regional economics through the in-group versus out-group rhetoric exacerbate societal attitudes and tensions of racial/ethnic animosities, hostilities, antagonism and, eventually, open violence (Gabel \& Scheve, 2007; Hopkins, 2010; Mafukata, 2015). Often, when xenophobic attacks and violent abuse of the immigrant out-group manifest, the polities tend to disown them without much reflection on the political rhetoric underlying attendant societal attitudes and public perceptions.

Whereas not always overt, political elites tend to adopt a political rhetoric that manipulates citizenry's insecurities to amass political mileage without careful considerations of the enduring effects on xenophobic societal attitudes and public perceptions. In the United States of America (USA), for example, the Republic Presidential Contender Donald Trump is presently drawing large crowds and leading polls through a rhetoric that demeans Mexicans as criminals, murderers and rapists. This political rhetoric appears to be outright racist and xenophobic. Establishing political support on xenophobic attitudes through fear and threat wherein out-groups are cast as the primary causes of the national social ills and economic problems, has almost always provoked anti-immigrants animosities, hostilities, antagonism and violence everywhere in the world (Golder, 2003; The Economist, 2011; Jolly \& DeGiusto, 2014; Adjai \& Lazaridis, 2013; Chinomona \& Maziriri, 2015; Mafukata, 2015). Whereas no one appears to be paying careful attention to the enduring legacies of Donald Trump political rhetoric's agitation of xenophobic public perceptions, the potential for future anti-out-group abuse and violence is real. The point to make is that the presence of immigrant out-groups in itself, should not serve both necessary and sufficient cause for xenophobic public attitudes. Equally, contact with the immigrant out-group itself does not precipitate societal attitudes and perceptions that drive animosities, hostilities, antagonism and violence within localities or nations. However, the effects of contact on the societal attitudes and perceptions (Jolly \& DiGiusto, 2014; Mafukata, 2015) are mediated through governance of egocentric exceptionalism and sociotropic differentness.

Polities would not readily openly concede that political party rhetoric, in an attempt to capture votes, plays a significant role in racial and ethnic animosities, hostilities and antagonism against the out-group minorities (Gabel \& scheve, 2007; Hopkins, 2010, 2011; Mafukata, 2015). Equally, governance of society in all its facets bears significant impacts on public perceptions that drive attitudes towards the immigrant out-groups. Thus, insight into xenophobia entails multidisciplinary theoretical integration that covers a range of subjects including governance, ef polities, inter-state relations, intra-state dynamics, socio-economic status, environmental conservation, demographic constitution of the population as well as cultural and traditional factors. As Jolly \& DiGiusto (2014: 471) put it, “... context is crucial” to understanding public perceptions that drive society's exclusionary preferences relating to immigrant out-groups. Apparently, these are the reasons why xenophobic violence in South Africa was, both in 2008 and 2015, directed exclusively against the African out-groups, rather than all immigrants. South African experiences affirm the significant role played by the myriad of governance structures, systems and process ranging across the spectrum of African 
recovery, environmental conservation, human settlement, services provisions, population policy and democratic constitutionalism, all of which are central to national identities that define South Africanness, differentness and exceptionalism. Hence, in trying to construct citizenship in the absence of cultural national identities, new South Africanism became deeply exclusionary and divisive.

Whereas the South African Police Services (SAPS) have been accused of using rudimentary and crude archaic techniques for apprehending people they thought are illegal immigrants, such as dark skin colour, hairstyle, size of shoes, clothes, accent and pronouncements of words, among other identification methods, this conduct was never sanctioned through state policy. In recent attempts to clear the streets of Johannesburg of crime, the state coined "operation fiela" which raised further eyebrows in terms of the negative societal perceptions that it strengthened against the out-group African immigrants, given the longstanding belief that the latter are responsible for the upward spike in crime. The ongoing scourge of Department of Home Affairs and Immigration Officers using coercion and abuses of human rights to solicit bribery, were never condoned through legislation or policy. According to Adjai \& Lazaridis (2013: 201), the democratic South Africa's first Immigration Act No. 13 of 2002 and the attendant political discourse promulgated xenophobic sentiments. The same sentiments were previously codified by Akokpari (2002), Bernstein (2005) and CDE (206, among others. However, this paper argues that any sense of xenophobic inclination in a democratic South Africa's legislation and policy would not have been by conscious design because reconstructing national identities on citizenship, in the absence of cultural commonalities, for the majority of apartheid victims was destined to be exclusionary and divisive. Such state actions have continued to reinforce societal perceptions that out-group African immigrants are a collective threat.

\section{Governance of South Africanism, differentness, exceptionalism and exclusionary citizenship for xenophobia}

A democratic South Africa is generally characterised as a "highly xenophobic society in which suspicion, fear, and rejection of foreigners create communal tensions that have negative political, social, and economic effects" (CDE, 2006: 8). The democratic state too has already been accused of being xenophobic and heavy-handed against African out-group immigrants (Akokpari, 2002; Bernstein, 2005; Zuberi \& Sibanda, 2005; CDE, 2006; Chinomona \& Maziriri, 2015). The editorial of The Star (23 July 2008: 14) describes the May 2008 events as "an orgy of xenophobic violence" wherein in-groups vented their frustrations and despair on African out-group immigrants, unfairly blaming them for the unmet post-1994 euphoric expectations of a better life for all. As Meyerson (2004) and Neumayer (2006) cautioned, the fact that the anti-immigrants drive has appeared to be grounded on racial/ethnic lines could also imply that the underlying debate and political rhetoric was itself devoid of any rational intellectual argument. Indeed, African out-group immigrants are perpetually exposed to alleged "xenophobic" hatred, rape, robbery and other fatal crimes (Mail and Guardian, 2006a). More instructive are the reports that "up to 25 percent of identity documents issued by Home Affairs could be illegal" (Sowetan, 2006: 1). Ina van der Merwe, the Chief Executive of Kroll South Africa - a risk analysis consultancy company specializing in verification of the authenticity of identity documents - confirmed that millions of identity documents issued by Home Affairs were illegal (SABC Special Assignment, 2006; Sowetan, 2006). She estimated a probability of "one in every four" identity documents being illegal (SABC Special Assignment, 2006; Sowetan, 2006). Furthermore, the reported improper use of 
illegally-acquired identity documents in 2006 marked a 29\% increase on that of 2005 as well as the claims that their abuse has since 1994 involved about R40 billion (Sowetan, 2006), exacerbate xenophobic societal attitudes and public perceptions. Significantly, reported abuse of identity documents could also involve claims on the state social welfare, with the implications that South Africans could construct negative xenophobic attitudes against the African out-groups (Neumayer, 2006). Such headlines make for enduring distorted images and negative stereotypes against the immigrant out-groups.

According to Turok (2006: 3), “obscene inequalities, poverty and joblessness” have remained pervasive in post-apartheid South Africa, creating therefore societal insecurities that the political elite could have opportunistically manipulated. Beyond complaining about jobs, pessimistic versions insist that "immigrants are a threat to the social and economic fabric of the nation" and are, therefore, unwanted competitors "for the scarce resources" because they "prevent the transition to a new economy in South Africa" (Zuberi \& Sibanda, 2005: 267). According to Bernstein (2005), South Africa's current policy framework is grounded in xenophobic intonations. The repeal and replacement of the Aliens Control Act with the new Immigration Act is adjudged to have reinforced the old bureaucratic apartheid procedures (Bernstein, 2005). According to the chairperson of the Committee on Immigration at South Africa's Law Society, Julian Pokroy, the many new amendments to the immigration policy have rectified the omissions in the existing law by re-enacting the old status quo (Mail $\mathcal{E}^{2}$ Guardian, 2006b). The new Immigration Act is blamed for attempting to protect South African jobs, thereby perpetrating the sentiments of the out-groups stealing jobs. Hence, the suggestion that South African immigration laws are rigid and xenophobic is an unfair characterization; instead, it is the attempt at the construction of citizenship for the formerly disenfranchised majority that became deeply exclusionary and divisive, unfairly casting the African out-group immigrants as the reason for all societal ills. For this reason, perceptions of collective threat, rather than reality, along with the construction of new South Africanisms, cannot be underestimated.

The public anti-immigration rhetoric has been that the African out-groups "take away jobs from South African nationals," and that immigrants are "an obstacle to economic integration for the African majority who are awaiting the gains in employment and living standards anticipated with the end of apartheid" (Zuberi \& Sibanda, 2005: 267). Government too responded to such sentiments by adopting policy measures that are allegedly "harsh," "hostile" and "notorious" (Akokpari, 2002; CDE, 2006; The Star, 2008). African immigrants are allegedly the most hated, severely dealt with and arrested, detained and deported from Lindela facility in South Africa (Akokpari, 2002; CDE, 2006). Akokpari (2002) describes the treatment of African immigrants as "immigration terrorism." For example, the CDE (2006) concludes that the Witbank community is characterised by stereotypes and hypocrisy wherein there exists, simultaneously, full acceptance for Europeans, ambivalence for Indians, Pakistanis and Chinese, as well as rejection of Nigerians, Mozambicans and Zimbabweans with variable degrees of dislike. Furthermore, CDE (2006: 7) reports that the community believes that African "immigrants caused overcrowding, utilized public services and amenities to which they were not entitled, spread disease, and ... were 'less civilized' than South Africans." These volatile beliefs have characterized the public debate, pointing to an old prejudice against African out-group immigrants. Colonisation and apartheid engendered a deep sense of disrespect and prejudice against Africans by fellow Africans; and, the psychology of this longstanding prejudice cannot be discounted from the xenophobic tendencies in a democratic South Africa. 
In an attempt to reconstruct South Africanism on African Renaissance and exclusionary citizenship, the state may have inadvertendly encouraged xenophobic attitudes. The White Paper on International Immigration documents that unskilled immigrants, a majority of whom are African, "compete for scarce jobs" and weaken state institutions through their involvement in criminal and fraudulent acts (RSA, 1999: 21). Hence, the South African society appears to be generally antagonistic towards African out-group immigrants, scapegoating the unfulfilled expectations and the post-1994 euphoria that remained unmatched by reality (Akokpari, 2002; CDE, 2006). It can be expected that "poor communities threatened by poverty, crime, and unemployment, in which people lack confidence as individuals and have the feeling of being victims themselves, and where their few resources of pride are in their own culture," could react negatively towards foreigners because their judgments become purely subjective, drawing from emotions and feelings of "insecurity and resentment of competition" (CDE, 2006: 9). The deep sense of South African exceptionalism and differentness defines the root of xenophobia against African out-groups in the democratic dispensation of rainbowism, multiculturalism and constitutional inclusivity.

A democratic South Africa's self-selection of leadership of African Renaissance and believe that the world wants this country to succeed, which was a mere exercise of puerility, provides a perfect example. In assuming such self-selected leadership, a democratic South Africa set out to enlighten Africa because its pursuit of African Renaissance, South-South Relations and the establishment of a new world order were couched through the preaching of peace, human right, liberalism, continental welfare, good governance, democracy, humane values and politico-economic recovery (Calland, 2013; Habib, 2013; Kotze, 2013). South Africa had hoped to establish itself as a credible champion and leader of African Renaissance on the bases of differentness and exceptionalism, which became an enduring presence in the societal imagination of a new South Africanism. In 1995, for example, South Africa embarked on a human rights crusade mobilising opposition against Nigeria's Sani Abacha following the hanging of Ken Saro-Wiwa (Habib, 2013). Perhaps, a democratic South Africa had genuine reasons to set itself as "a voice of reason for voiceless Africa" (Vale \& Maseko, 1998; Calland, 2013; Habib, 2013), but the long-term societal impacts of this official construction of a new South Africanism have become evidently deleterious.

For reasons of its attempts at African Renaissance leadership, Premhid (2014: n.p.) labels South Africa as a "pretender to the role of regional hegemon." According to Marais (2001: 251), the official belief that the world wanted South Africa to succeed was in harmony with this country's "self-image of distinctiveness and superiority vis-à-vis the rest of the continent - thereby resonating with the pervasive sense of differentness and superiority frequently encountered and remarked upon by visiting foreigners." The pursuit of leadership and championship of African Renaissance on the bases of South African differentness and exceptionalism was itself paradoxical and contradictory. Hence, Vale \& Maseko (1998) emphatically warned that South Africa should not have even attempted to lead African Renaissance when the central tenet was so deeply and overtly paradoxical. Conclusively, South Africanisms official state policy on Africa and citizenship contributed to societal attitudes of xenophobia against out-group African immigrants.

Additionally, the South African government itself spearheaded the process of citizenship reconstruction that is deeply discriminatory because of the emphasis on differentness and exceptionalism. Arising from a history of racial discrimination against the majority Africans, South Africa sought to establish a new national identity which remained a virtual pipedream under the desperate in-groups' cultures that contradicted and, in some cases, contested 
validity of each other. The most pragmatic route was to create such national identity through citizenship, which inevitably became exclusionary because the out-groups did not meet the criteria and were excluded (Weldon, 2006; Adjai \& Lazaridis, 2013; Chinomona \& Maziriri, 2015). Domestically too, the construction of national identity through exclusionary citizenship has been deeply fragmentary with different levels for Gauteng and Western Cape versus all other provinces. For the in-groups, this concept implied "inclusivity," "belongingness and ownership" (Adjai \& Lazaridis, 2013; Chinomona \& Maziriri, 2015; Mafukata, 2015) albeit fragmentary and unequal. The inevitable outcome of the adoption of the concept of citizenship for establishment of national identities is that it characterized people as "insiders and outsiders" or "in-groups and out-groups" (Adjai \& Lazaridis, 2013; Chinomona \& Maziriri, 2015; Mafukata, 2015). Whereas the creation of the national identity was predicated on the notion of citizenship, which was simultaneously protected through legislative instruments (Adjai \& Lazaridis, 2013; Chinomona \& Maziriri, 2015; Mafukata, 2015), there was no official conscious structural xenophobic ideology that was governed through "rules, laws, regulations and institutions". To this extent, notwithstanding the various commonalities of the manifestations of xenophobia and "new racism," South Africa's xenophobia cannot be tenably characterised as "new racism."

The promise of national identity built on exclusionary citizenship was for the regulation of "access to state and public resources" (Adjai \& Lazaridis, 2013; Chinomona \& Maziriri, 2015; Mafukata, 2015), which remained unrealized. The frustration and anger attendant to this unrealized better life for all, translated into xenophobic attitudes, animosities, antagonism and abusive violence against the out-group African immigrants due to the psychology of exceptionalism and differentness. This paper has already pointed to state constructions of citizenship, domestically and internationally, which exploited the notions of exceptionalism and differentness, thereby shaping societal perceptions of Africans and outgroups in particular. As to the abusive violence, it should be examined through the apparent abandonment of the original promise of the establishment of the national identity around the notion of citizenship. In the critique of South Africa's most recent reflexivity in the 2012 National Development Plan (NDP) 2030, Alloggio \& Thomas (2013: 109) poignantly state:

The rhetoric of active citizenry adds insult to injury: those who suffered the worst forms of injustice under apartheid are now liberal subjects who are cast as responsible for their failure to transcend and transform the harshness of life post-apartheid.

First, it was the 1996 Growth, Employment and Redistribution (GEAR) which, through neoliberal reflexive global modernity, led to the 2006 Accelerated Shared Growth in South Africa (AsgiSA) and then the 2012 NDP 2030, both of which remained synonymous with societal inequalities, severe poverty, crime and enduring service delivery backlogs. As Adjai \& Lazaridis (2013: 194) put it, the politics of access in a democratic South Africa meant that xenophobia became "an expression of disillusionment of the government's inability to deliver" the promise of exclusionary citizenship where the out-group African immigrants are victims, in accordance with the societal perceptions that the state had itself established over the years of failed attempts to lead and champion African Renaissance. Indeed, post-apartheid South Africanism has exhibited "high levels of xenophobia towards fellow African citizens, subjecting them to different forms of prejudice and discrimination" (Adjai \& Lazaridis, 2013: 192) with an amazing dose of irrationality. The alibis of "fear" about employment opportunities and income, stealing of women and accepting of hazardous jobs at below minimum wages have been dismissed as jealously-related scapegoats because most out-group African immigrants are entrepreneurial (Akokpari, 2002; Chinomona \& Maziriri, 2015; 
Mafukata, 2015). However, new South Africanism and the attendant xenophobia cannot be tenably characterised as "new racism" as there have been no state rules intended for its reproduction.

\section{Conclusion}

This article has discussed the theorisation of the causes of societal attitudes of xenophobia against the out-groups in order to identify the constructions of collective threat as a fundamental ingredient in the governance of public antagonism, animosities and violent abuse. Attempts to lead African Renaissance based on a new South Africanisms, exceptionalism and differentness created an enabling environment for societal tensions against the African out-groups. Furthermore, the article linked the notion of collective perception of threat to unintended contextual consequences of South Africa's governance of national identities around exclusionary and divisive citizenship. However, the paper rejects the insinuation that the new South Africanism is an expression of "new racism" because there are no rules enforced for reproduction of such societal attitudes of xenophobia. In the absence of any cultural commonalities for the reconstruction of national identities in a democratic era, new South Africanism relied on citizenship with inevitable emphasis on exceptionalism and differentness that bore deleterious consequences for the African out-group immigrants.

\section{References}

Adjai, C. \& Lazaridis, G. 2013. Migration, xenophobia and new racism in post-apartheid South Africa. International Journal of Social Science Studies, 1(1): 192-205.

Akokpari, J.K. 2002. International migration, xenophobia and the dilemma of the South African State. In Buthelezi, S. \& Le Roux, E. (eds.), South Africa Since 1994: Lessons and Prospects. Pretoria: AISA, pp.221-246.

Alloggio, S. \& Thomas, K. 2013. Resisting the lure of deferral: Realizing the South African National Development Plan. Social Dynamics: A Journal of African Studies, 39(1): 108110.

Allport, G. 1954. The Nature of Prejudice. Cambridge, MA: Addison-Wesley.

Balbo, M. \& Marconi, G. 2006. International migration, diversity and urban governance in cities of the South. Habitat International, 30: 706-715.

Bernstein, A. 2005. Bring us your skilled masses. Business Day, 17 March 2005, p.11.

Brinegar, A. \& Jolly, S. 2005. Location, location, location: National contextual factors and public support for European integration. European Union Politics, 6(2): 155-180.

Brown, R.P.C. \& Connell, J. 2004. The migration of doctors and nurses from South Pacific Island Nations. Social Science and Medicine, 58: 2193-2210.

Brown, L.M. \& Lopez, G.E. 2001. Political contacts: Analyzing the role of similarity in theories of prejudice. Political Psychology, 22(2): 279-292.

Burns, P. \& Gimpel, J. 2000. Economic insecurity, prejudicial stereotypes, and public opinion on immigration policy. Political Science Quarterly, 155(2): 201-225.

Calland, R. 2013. The Zuma Years: South Africa's Changing Face of Power. Cape Town: Zebra Press. 
Centre for Development \& Enterprise (CDE), 2006. Immigrants in South Africa: Perceptions and Reality in Witbank, a Medium-sized Industrial Town. CDE Focus No. 9, May 2006, Johannesburg.

Chinomona, E. \& Maziriri, E.T. 2015. Examining the phenomenon of xenophobia as experienced by African immigrant entrepreneurs in Johannesburg, South Africa: Intensifying the spirit of "Ubuntu." International Journal of Research in Business Studies and Management, 2(6): 20-31.

City Press, 2006. 'We'd rather die at home:' Somali nationals say there's no peace for them in SA. 12 November 2006, p.13.

City Press, 2008. Brain drain knocks SA. 21 September 2008, p.17.

De Sante, C.D. 2013. Working twice as hard to get half as far: Race, work ethic, and America's deserving poor. American Journal of Political Science, 57(2): 342-356.

Gabel, M. \& Scheve, K. 2007. Estimating the effect of elite communications on public opinion using instrumental variables. American Journal of Political Science, 51(4): 10131028.

Gade, C.B.N. 2011. The historical development of written discourse on Ubuntu. South African Journal of Philosophy, 30(3): 304-332.

Golder, M. 2003. Explaining variation in the success of extreme right parties in western Europe. Comparative Political Studies, 36(4): 432-466.

$\mathrm{Ha}$, S. 2010. The consequences of multiracial contexts on public attitudes toward immigration. Political Research Quarterly, 63(1): 29-42.

Habib, A. 2013. South Africa's Suspended Revolution: Hopes and Prospects. Johannesburg: Wits University Press.

Hainmueller, J. \& Hiscox, M.J. 2007. Educated preferences: Explaining attitudes toward immigration in Europe. International Organization, 61: 399-442.

Hainmueller, J. \& Hiscox, M.J. 2010. Attitudes toward highly skilled and low-skilled immigration: Evidence from a survey experiment. American Political Science Review, 104(1): 1-24.

Heilmann, C. 2006. Remittances and the migration-development nexus: challenges for the sustainable governance of migration. Ecological Economics, 59: 231-236.

Hjerm, M. 2009. Anti-immigrant attitudes and cross-municipal variation in the proportion of immigrants. Acta Sociologica, 52(1): 47-62.

Hopkins, D.J. 2010. Politicized places: Explaining where and when immigrants provoke local opposition. American Political Science Review, 104(1): 40-60.

Hopkins, D.J. 2011. National debates, local responses: The origins of local concern about immigration in Britain and the United States. British Journal of Political Science, 41(3): 499-524.

Jennings, W. 2009. The public thermostat, political responsiveness and error-correction: Border control and asylum in Britain, 1994-2007. British Journal of Political Science, 39: 847-870. 
Jolly, S.K. \& DiGiusto, G.M. 2014. Xenophobia and immigrant contact: French public attitudes towards immigration. The Social Science Journal, 51: 464-473.

Kessler, A.E. \& Freeman, G.P. 2005. Public opinion in the EU on immigration from outside the community. Journal of Common Market Studies, 43(4): 825-850.

Khomba, J.K., Vermaak, F.N.S. \& Gouws, D.G. 2011. Redesigning an innovation section of the balanced scorecard model: An African perspective. Southern African Business Review, 15(3): 1-20.

Kopstein, J.S. \& Wittenberg, J. 2009. Does familiarity breed contempt? Inter-ethnic contact and support for illiberal parties. Journal of Politics, 71(2): 414-428.

Kotze, D. 2013. South Africa's foreign policy and international relations during 2012. In Jansen, J.D., Nyamnjoh, F., Pillay, U. \& Hagg, G. (eds.), State of the Nation: South Africa 2012-2013 - Addressing Inequality and Poverty. Pretoria: HSRC.

Lahav, G. 2004a. Immigration and Politics in the New Europe. Cambridge, MA: Cambridge University Press.

Lahav, G. 2004b. Public opinion toward immigration in the European Union: Does it matter? Comparative Political Studies, 37(10): 1151-1183.

Mabovula, N.N. 2011. The erosion of African communal values: A reappraisal of the African Ubuntu philosophy. Journal of Human and Social Sciences, 3(1): 38-48.

Mafukata, M.A. 2015. Xenophobia: The evil story of the beginnings of fascism in postapartheid South Africa. The International Journal of Humanities and Social Studies, 3(3): 30-44.

Mail E Guardian, 2006a. A tragic trade. 01-07 December 2006, p.12.

Mail \& Guardian, 2006b. Skilled foreigners tied up in red tape. 10-16 November 2006, p.16.

Marais, H. 2001. South Africa: Limits to Change, The Political Economy of Transition, $2^{\text {nd }}$ edn. Cape Town: University of Cape Town Press.

McLaren, L.M. 2003. Anti-immigrant prejudice in Europe: Contact, threat perception, and preferences for the exclusion of migrants. Social Forces, 81(3): 909-936.

McLaren, L.M. 2007. Explaining opposition to Turkish membership of the EU. European Union Politics, 8(2): 251-278.

McLaren, L. \& Johnson, M. 2007. Resources, group conflict and symbols: Explaining antiimmigration hostility in Britain. Political Studies, 55: 709-732.

Meyerson, F.A.B. 2004. Policy view: immigration, population policy, and the sierra club. Population and Environment, 26(1): 61-69.

Neumayer, E. 2006. The environment: one more reason to keep immigrants out? Ecological Economics, 59: 204-207.

Ngoiyaza, B. \& Rondganger, L. 2008. We have been treated very badly here: cops on hand as bitter refugees leave Joburg camp peacefully. The Star 23 July 2008, p.3.

Premhid, K. 2014. Zuma's foreign policy drift. Nerws24, http://voices.news24.com/kameelpremhid/2014/03/zumas-foreign-policy-drift/ [Accessed: 10 March 2014]. 
Republic of South Africa (RSA), 1999. White Paper on International Migration. Pretoria: Government Printers.

Rink, N., Phalet, K. \& Swyngedouw, M. 2009. The effects of immigrant population size, unemployment, and individual characteristics on voting for the Vlaams Blok in Flanders 1991-1999. European Sociological Review, 25(4): 411-424.

Rudolph, T.J. \& Popp, E. 2010. Race, environment, and interracial trust. Journal of Politics, 72(1): 74-89.

Ryan, E. 2008. Skills exodus is becoming a problem: while many people are immigrating to SA, more are leaving. Mail E Guardian, 09 to 15 May 2008, p.3.

SABC Special Assignment, 2006. Fraudulent South African ID documents issued by corrupt Home Affairs officials. 31 October 2006, Johannesburg.

Schneider, S.L. 2008. Anti-immigrant attitudes in Europe: Outgroup size and perceived ethnic threat. European Sociological Review, 24(1): 53-67.

Sniderman, P., Hagendoorn, L. \& Prior, M. 2004. Predisposing factors and situational triggers: Exclusionary reactions to immigrant minorities. American Political Science Review, 98(1): 35-49.

Sowetan, 2006. The big ID stink. 01 November 2006, pp.1, 4.

Soyombo, O. 2008. Xenophobia in contemporary society: A sociological analysis. IFE Psychologia, 16(2): 85-104.

Taylor, M.J., Moran-Taylor, M.J. \& Ruiz, D.R. 2006. Land, ethnic, and gender change: transnational migration and its effects on Guatemalan lives and landscapes. Geoforum, 37: 41-61.

The Economist, 2011. The growth of Islamophobia: Can careless talk cost lives? The Economist, 30 July 2011, p.23.

The Star, 2008. A struggle against hate. 23 July 2008, p.14.

Turok, B. 2006. The challenge of managing capitalism. Umrabulo, 27(November): 3-9.

Vale, P. \& Maseko, S. 1998. South Africa and the African Renaissance. International Affairs, 74(2): 271-287.

Van der Merwe, P. 2002. South Africa's brand challenge. Business in Africa, 10(8): 20-28.

Vincent, L. 2008. The limitations of “inter-racial contact:" Stories from young South Africa. Ethnic and Racial Studies, 31(8): 1426-1451.

Weldon, S.A. 2006. The institutional context of tolerance for ethnic minorities: A comparative, multilevel analysis of western Europe. American Journal of Political Science, 50(2): 331-349.

Zuberi, T. \& Sibanda, A. 2005. Migration and employment. In: Zuberi, T., Sibanda, A. \& Udjo, E. (eds.), The Demography of South Africa. London: M.E. Sharpe, pp.266-296. 